\title{
Financial cost of whole blood and blood component disposals in a Brazilian coordinating blood center
}

\author{
Custo financeiro dos descartes de sangue total e hemocomponentes \\ em um hemocentro coordenador brasileiro
}

Costo financiero de los desechos de sangre total y hemocomponentes en un hemocentro coordinador brasileño

\section{Magali Zimmermann Covo ${ }^{\mathrm{a}, \mathrm{b}}$ Elaine Drehmer de Almeida Cruz ${ }^{\mathrm{a}}$ \\ Aline Batista Maurício ${ }^{a}$ Josemar Batista ${ }^{a}$ Liana Andrade Labres de Souza ${ }^{b}$}

How to cite this article: Covo MZ, Cruz EDA, Mauríic AB, Batista J, Souza LAL. Financial cost of whole blood and blood component disposals in a Brazilian coordinating blood center. Rev Gaúcha Enferm. 2019:40:e20190033. doi: https://doi.org/10.1590/19831447.2019.20190033 a Universidade Federal do Paraná (UFPR), Programa de Pós-Graduação em Enfermagem. Curitiba, Paraná, Brasil.

Centro de Hematologia e Hemoterapia do Paraná (HEMEPAR). Curitiba, Paraná, Brasil.

\section{ABSTRACT}

Objective: To describe the reasons for the disposal of blood in the coordinating blood center of the State of Paraná and to estimate the financial costs resulting from potentially avoidable discards.

Method: A descriptive, retrospective and documentary analysis, with data related to the period from 2010 to 2015 of a Brazilian coordinating blood center collected from a governmental database and analyzed by descriptive statistics. This study was approved by the Ethics Research Committee (CAEE 63074916.0.0000.5225).

Results: 101,813 units were discarded, representing $22.3 \%$ of the total of 455,684 produced; plasma was the most discharged blood component. The main reason for discarding was lipemia (35.8\%); the analysis showed that $56.9 \%$ of the disposals were considered potentially avoidable with an estimated paid value of approximately US\$2 million.

Conclusion:The expressive potential of avoidance of disposal of blood units and blood components highlights the importance of planning actions aiming at their best use, contributing to the reduction of amounts paid for these processes.

Keywords: Blood banks. Date of validity of products. Blood preservation. Cost savings.

\section{RESUMO}

Objetivo: Descrever os motivos de descarte de sangue no hemocentro coordenador do Estado do Paraná e estimar os custos financeiros decorrente de descartes potencialmente evitáveis.

Método: Descritivo, retrospectivo e análise documental, cujos dados relativos ao período de 2010 a 2015 foram coletados a partir de base do Sistema Hemovida, e analisados por estatística descritiva. 0 projeto foi aprovado pelo Comitê de Ética em Pesquisa sob CAEE 63074916.0.0000.5225.

Resultados: Foram descartadas 101.813 unidades, que representaram 22,3\% do total de 455.684 produzidas; 0 plasma foi 0 hemocomponente mais descartado. Houve prevalência de descarte por lipemia (35,8\%); a análise demonstrou que 56,9\% dos descartes foram considerados potencialmente evitáveis, um valor pago estimado de US\$2 milhões.

Conclusão: 0 expressivo potencial de evitabilidade de descarte de unidades de sangue e hemocomponentes destaca a importância no planejamento de ações com vistas ao seu melhor uso, contribuindo para a redução de valores pagos para esses processos.

Palavras-chave: Bancos de sangue. Prazo de validade de produtos. Preservação de sangue. Redução de custos.

\section{RESUMEN}

Objetivo: Describir las causas de desechos de sangre en un hemocentro coordinador del estado de Paraná y estimar los costos financieros recurrentes de desechos potencialmente evitables.

Método: Descriptivo, retrospectivo y análisis documental, con datos relativos al período de 2010 a 2015 de un hemocentro coordinador brasileño recolectados a partir de la base del Sistema Hemovida y analizados por estadística descriptiva. El proyecto fue aprobado por el Comité de Ética en Investigación con el número CAEE 63074916.0.0000.5225.

Resultados: Se desecharon 101.813 unidades, lo que representa el 22,3\% del total de 455.684 producidas; el plasma fue el hemocomponente más desechado. Hubo predominio de desecho por lipemia (35,8\%); y el análisis demostró que el 56,9\% de los desechos se consideraron potencialmente evitables, un valor pago estimado de US\$2 millones.

Conclusión: El significativo potencial de evitar el desecho de unidades de sangre y hemocomponentes destaca la importancia de planificar acciones con vistas a mejorar el uso, contribuyendo así a reducir los costos de las tarifas que se pagan por estos procesos.

Palabras clave: Bancos de sangre. Fecha de caducidad de los productos. Conservación de la sangre. Reducción de costos. 


\section{口INTRODUCTION}

Blood products are defined as therapeutic substances derived from human blood constituents, including whole blood, blood components and blood products, which are used in medical and surgical interventions, saving millions of lives annually. To ensure the safety of the recipients, the World Health Organization recommends that all stages of the blood cycle, from donor uptake to transfusion, be coordinated by integrated blood supply networks ${ }^{(1)}$.

In Brazil, the regulation, supervision and control of blood products and services are performed by the National Health Surveillance Agency (Agência Nacional de Vigilância Sanitária - ANVISA) according to the Ministry of Health. The hemotherapy services integrate, in federal instance, the national blood network, composed in each state of the federation by a coordinating blood center, regional blood centers, blood nucleus and collection and transfusion units. The coordinating blood center, of a public nature, has a central role and should be a reference service for the respective state in the area of hemotherapy and/or hematology. The regional blood center has macroregional activity while the hemotherapy nucleus acts in the respective microregion. Collection and transfusion units have lower care complexity ${ }^{(2)}$. Thus, it is observed that Brazil has an organized system in which each state of the federation is responsible for the collection, processing and distribution network. As such, each coordinating blood center needs to improve its processes to meet the blood needs of the hospitals it serves.

This organization, recommended by the country's Blood and Blood Products Policy, is meeting the growing number of blood samples in the world. Brazil follows this expansion and presented, in 2014, an increase of 162,446 blood collection procedures in relation to the previous year; in the country, donations are characterized as voluntary and altruistic ${ }^{(3-4)}$. Considering this type of blood donation and the financial values of its processing, rational use is desired, observing the necessary and legal steps of safe use.

Blood transfusion, like any therapeutic practice, has its risks. Among the strategies for reducing diseases, clinical screening represents a primordial stage, considering the information reported by the donor candidate regarding the advancing and current state of health and life habits. And certain situations or behaviors, such as alcohol consumption and illicit drugs that signal additional risk for sexually transmitted infections, impact on the results of the serological screening step ${ }^{(5)}$.
In Brazil, blood centers provide blood and blood components to health services and are reimbursed by the state based on the Unified Health System's financial table, last updated in $2006^{(6)}$. For example, when providing a unit of whole blood, the blood center receives $\mathrm{R} \$ 285$ or US\$75.8.

Given the goal of risk-free blood use, regulatory bodies intend to minimize transfusion incidents, ensure safe transfusions, and determine whether or not to use collected blood. In this context, blood or blood component disposal should be performed whenever the product is considered inappropriate for use due to factors interfering with blood cycle safety and related to collection conditions, risk behavior or reactive serology, failure of storage or transport and expiration of product(5).

In the disposal, besides the technical aspects, the financial value must be considered. According to an estimate made by the World Health Organization, only the disposal of packed red blood cells in Latin American and Caribbean countries in 2011 represented a loss of approximately US\$ 45 million, with a corresponding cost of US\$ 20 million US dollars to the Brazilian state ${ }^{(7)}$. This scenario prompts the need to know the factors that influence the disposal of processed blood units, in order to list actions to prevent those considered potentially avoidable.

In the southern region of Brazil, the state of Paraná stands out in the absolute number of collections, specifically in production with an increase of approximately 20\% between 2012 and 2015 ${ }^{(3,8)}$. Therefore, the existence of productive growth and financial impact is well known; however, Paraná leads in number of cases of unfit donors among other states in the region ${ }^{(3)}$.

Considering the economic impact and social repercussion of blood collection, processing and use in health services, with a view to subsidizing actions to minimize waste, contribute to the growth of blood supply and reduce the financial impact on the public sector, we have the following as research question: "What are the reasons for blood disposal in the coordinating blood center of Paraná and the financial cost of potentially avoidable discharges?" And the objectives are to describe the reasons for blood disposal in the coordinating blood center of the state of Paraná and to estimate the financial costs resulting from potentially avoidable discharges.

${ }^{1}$ Considering the value of the commercial US dollar against the real on January 27, 2019 (R\$3.76), according to the website https://www.dolarhoje.net.br. 


\section{MATERIAL AND METHODS}

It is a descriptive research, with a retrospective quantitative approach and documentary analysis. Data collection took place between January and May 2017 and was developed from secondary databases related to the disposal of blood components of the coordinating blood center of Paraná, located in the state's capital. The center is responsible for the collection, storage, processing, transfusion and distribution of blood to 384 public, private and philanthropic hospitals in the state ${ }^{(9)}$

The study included all reported cases of whole blood and blood component disposal occurring from January 2010 to December 2015 and recorded in the Hemovida System. The temporal cutoff is justified due to the use of data from the referred System, which was developed and implemented specifically for blood banks, and was effective until 2015(10). Data were used from technical reports were used complementarily; and inconsistent data due to possible typing errors and/or inadequate records were excluded after analysis and consensus among the researchers.

The variables analyzed were the quantity of bags produced and discarded of packed red blood cells, platelet concentrate, cryoprecipitate, common plasma, fresh frozen plasma, cryoprecipitate-free plasma, and whole blood. Disposal reasons were also analyzed, and these were classified as potentially avoidable and non-avoidable by a committee of three specialists with over 20 years of experience in the areas of Hematology and Hemotherapy. Data recorded in the "other reasons" field of the Hemovida System were classified as unavoidable because the causes could not be known.

To estimate the financial costs of disposals, the amounts paid, in reimbursement, to health services related to blood components were used, as shown in Chart 1, in force in the year of the information document and estimated in dollar (\$) value in the current period ${ }^{(6)}$.

\begin{tabular}{|l|c|c|}
\hline \multicolumn{1}{|c|}{ Blood components or Procedures } & \multicolumn{2}{c|}{ Reference value } \\
\cline { 2 - 3 } Operational costs* of whole blood & Real (R\$) & Dollar (US\$) ${ }^{1}$ \\
\hline RBC concentrate operating costs & 285.00 & 73.83 \\
\hline Operating costs of random platelet concentrate & 150.00 & 38.86 \\
\hline Operating costs of fresh frozen plasma & 135.00 & 34.97 \\
\hline Cryoprecipitate operating costs & 125.00 & 32.38 \\
\hline
\end{tabular}

Chart 1 - Reference value for reimbursement to hemotherapy services provided to the Unified Health System and private health institutions in Brazil in 2006. Curitiba, PR, Brazil, 2017

Source: Adapted from the Ministry of Health (2006)

* Operational costs are to be understood as: values related to consumables, materials, serological tests, immuno-hematological and other laboratory tests, performed for the selection of said biological materials, as well as fees for medical services.

'Considering the value of the commercial US dollar against the real on January 27, 2019 (R\$3.76), according to the website https://www.dolarhoje.net.br.

The variables of interest were extracted from the System database and included in the Microsoft Office Excel, by double typing, followed by checking and correcting inconsistencies. After the synthesis of the information, data were analyzed by descriptive statistics and presented in absolute and relative frequencies.

This study is part of the professional following master's dissertation: Matrix of Recommendations for
Improving Blood Cycle Performance at the Coordinator Blood Center of the State of Paraná(11). Compliance with the Human Research Guidelines and Standards established by Resolution 466/12 and 510/2016 from the Ministry of Health of Brazil, and obtained approval from the Ethics Committee on Research with Human Beings of the Worker's Hospital - Health Department of the State of Paraná, under CAAE (Certificado de Apresentação para 
Apreciação Ética, Presentation Certificate for Ethical Appreciation) number 63074916.0.0000.5225 and opinion No. 1.898.252.

\section{RESULTS}

Between 2010 and 2015, 455,684 bags of whole blood and blood components were produced in the coordinating blood center of Paraná, and 101,814 units (22.3\%) were discarded. Red blood cell concentrate, platelet concentrate, and fresh frozen plasma totaled $89.7 \%$ $(n=408,690)$ of the produced product, with a respective more prevalent disposal (85.7\%; $n=87,271)$. Common plasma disposal represented the highest relative frequency of discharges (80.2\%), as shown in Table 1.

Table 1 - Relationship between production and disposal of whole blood and blood components in the coordinating blood center of the State of Paraná from 2010 to 2015. Curitiba, PR, Brazil, 2017

\begin{tabular}{|c|c|c|c|}
\hline \multirow[t]{2}{*}{ Variables } & Production & Discard & \multirow{2}{*}{$\begin{array}{l}\text { Discard in relation to } \\
\text { production (\%) }\end{array}$} \\
\hline & n (\%) & n (\%) & \\
\hline Red blood cell concentrate & $177,543(39.0)$ & $11,645(11.4)$ & 6.6 \\
\hline Platelet concentrate & $85,795(18.8)$ & $21,699(21.3)$ & 25.3 \\
\hline Cryoprecipitate concentrate & $25,885(5.7)$ & $3,045(3.0)$ & 11.8 \\
\hline Common plasma & $12,024(2.6)$ & $9,649(9.5)$ & 80.2 \\
\hline Fresh frozen plasma & $145,352(31.9)$ & $53,927(53.0)$ & 37.1 \\
\hline Whole blood & $9,085(2.0)$ & $1,849(1.8)$ & 20.4 \\
\hline Total & $455,684(100.0)$ & $101,814(100.0)$ & 22.3 \\
\hline
\end{tabular}

The main reasons for whole blood and blood component disposal for potentially avoidable causes are presented in Table 2. There was a higher prevalence of discards in this regard, corresponding to $56.9 \%(n=57,971)$ in relation to unavoidable causes (Table 4). Potentially avoidable reasons include the prevalence of lipemia (35.8\%), followed by red blood cell contamination (17.5\%) and reactive serology (16.7\%).

Table 2 - Distribution of the reasons for discarding blood components in the coordinating blood center of the State of Paraná from 2010 to 2015 by potentially avoidable causes ( $n=57,971)$. Curitiba, PR, Brazil, 2017

\begin{tabular}{|c|c|c|c|c|c|c|c|}
\hline \multirow{2}{*}{$\begin{array}{l}\text { Discards for potentially preventable } \\
\text { causes }\end{array}$} & $\mathbf{C H}$ & CP & CRIO & PC & PFC & ST & Total \\
\hline & n (\%) & n (\%) & n (\%) & n (\%) & n (\%) & n (\%) & n (\%) \\
\hline \multirow{2}{*}{$\begin{array}{l}\text { Defrosting and/or } \\
\text { improper storage/transport }\end{array}$} & 346 & 240 & 116 & 7 & 634 & 12 & 1,355 \\
\hline & (5.0) & (1.4) & (6.9) & $(0.5)$ & $(2.0)$ & $(2.4)$ & (2.3) \\
\hline \multirow{2}{*}{ RBC contamination } & 1 & 6,445 & 54 & 171 & 3,476 & 0.0 & 10,147 \\
\hline & $(0.0)$ & (39.6) & (3.2) & (13.3) & $(11.1)$ & $(0.0)$ & $(17.5)$ \\
\hline
\end{tabular}


...continuation

\begin{tabular}{|c|c|c|c|c|c|c|c|}
\hline \multirow{2}{*}{$\begin{array}{l}\text { Discards for potentially preventable } \\
\text { causes }\end{array}$} & $\mathrm{CH}$ & $\mathbf{C P}$ & CRIO & PC & PFC & ST & Total \\
\hline & n (\%) & n (\%) & n (\%) & n (\%) & n (\%) & n (\%) & n (\%) \\
\hline \multirow{2}{*}{$\begin{array}{l}\text { Cryo not produced-performed } \\
\text { special procedure }\end{array}$} & 0 & 0 & 526 & 2 & 32 & 0 & 560 \\
\hline & $(0.0)$ & $(0.0)$ & $(31.2)$ & $(0.2)$ & $(0.1)$ & $(0.0)$ & $(1.0)$ \\
\hline \multirow{2}{*}{ Returned without conditions of use } & 632 & 236 & 121 & 4 & 1,114 & 0 & 2,107 \\
\hline & $(9.1)$ & $(1.4)$ & $(7.2)$ & $(0.3)$ & (3.6) & $(0.0)$ & (3.6) \\
\hline \multirow{2}{*}{$\begin{array}{l}\text { Improper identification and/or donor } \\
\text { registration error }\end{array}$} & 7 & 85 & 7 & 0 & 586 & 0 & 685 \\
\hline & $(0.1)$ & $(0.5)$ & $(0.4)$ & $(0.0)$ & (1.9) & $(0.0)$ & $(1.2)$ \\
\hline \multirow{2}{*}{ Hematocrit below parameter ${ }^{1}$} & 17 & 0 & 0 & 0 & 0 & 0 & 17 \\
\hline & $(0.2)$ & $(0.0)$ & $(0.0)$ & $(0.0)$ & $(0.0)$ & $(0.0)$ & $(0.0)$ \\
\hline \multirow{2}{*}{ Hemoglobin <45 g } & 305 & 3 & 0 & 0 & 4 & 0 & 312 \\
\hline & $(4.4)$ & $(0.0)$ & $(0.0)$ & $(0.0)$ & $(0.0)$ & $(0.0)$ & $(0.5)$ \\
\hline \multirow{2}{*}{ Hemolysis } & 119 & 21 & 0 & 12 & 269 & 1 & 422 \\
\hline & $(1.7)$ & $(0.1)$ & $(0.0)$ & $(0.9)$ & $(0.9)$ & $(0.2)$ & $(0.7)$ \\
\hline \multirow{2}{*}{ Lipemia } & 6 & 1,600 & 263 & 805 & 18,047 & 9 & 20,730 \\
\hline & $(0.1)$ & $(9.8)$ & $(15.6)$ & $(62.4)$ & $(57.8)$ & (1.8) & $(35.8)$ \\
\hline \multirow{2}{*}{ Presence of lumps, fibrin or clot } & 17 & 453 & 10 & 19 & 95 & 2 & 596 \\
\hline & $(0.2)$ & $(2.8)$ & $(0.6)$ & $(1.5)$ & $(0.3)$ & $(0.4)$ & $(1.0)$ \\
\hline \multirow{2}{*}{ Reagent serology } & 4,505 & 1,921 & 478 & 222 & 2,546 & 0 & 9,672 \\
\hline & $(64.6)$ & $(11.8)$ & $(28.3)$ & $(17.2)$ & $(8.1)$ & $(0.0)$ & $(16.7)$ \\
\hline \multirow{2}{*}{ Swirling $<2 t^{2}$} & 106 & 1,437 & 60 & 1 & 165 & 0 & 1,769 \\
\hline & $(1.6)$ & (8.8) & (3.6) & $(0.1)$ & $(0.5)$ & $(0.0)$ & (3.1) \\
\hline \multirow{2}{*}{ Maturity with or without serology } & 687 & 3,272 & 11 & 0 & 43 & 73 & 4,086 \\
\hline & (9.8) & $(20.1)$ & $(0.7)$ & $(0.0)$ & $(0.1)$ & $(14.8)$ & $(7.0)$ \\
\hline \multirow{2}{*}{ Whole blood volume $>495 \mathrm{ml}$} & 0 & 10 & 1 & 3 & 324 & 205 & 543 \\
\hline & $(0.0)$ & $(0.1)$ & $(0.1)$ & $(0.2)$ & $(1.0)$ & $(41.7)$ & $(0.9)$ \\
\hline \multirow{2}{*}{ Volume out of parameters } & 227 & 559 & 40 & 44 & 3,910 & 190 & 4,970 \\
\hline & (3.3) & (3.4) & $(2.4)$ & (3.4) & $(12.5)$ & (38.6) & (8.6) \\
\hline \multirow{2}{*}{ Total } & 6,975 & 16,282 & 1,687 & 1,290 & 31,245 & 492 & 57,971 \\
\hline & $(100.0)$ & $(100.0)$ & $(100.0)$ & $(100.0)$ & $(100.0)$ & $(100.0)$ & $(100.0)$ \\
\hline
\end{tabular}

Source: Hemovida/Datasus, 2017

Caption: CH: Red blood cell concentrate; (P: Platelet concentrate; CRIO: Cryoprecipitate; PC: Common plasma; PFC: Fresh frozen plasma; ST: Whole blood.

${ }^{1}$ Hematocrit below parameter: Red cell concentrates without an additive solution should have a hematocrit between $65 \%$ and $80 \%$. In the case of bags with an additive solution, hematocrit may vary from 50 to $70 \%$.

Swirling <2+: A test performed on platelet concentrates that allows the identification of opalescence (cloud or wave formation) in the supernatant plasma, which indicates its ability to cause aggregation. 
Other reasons not listed in Hemovida like excess plasma stocks, female plasma, previous self-exclusion for less than a year and positive donor antibody screening for previous donation accounted for the highest frequency of discards among the unavoidable causes (24.6\%), followed by abnormal staining (23.9\%) and by the use for quality control (19.9\%), as described in Table 3.

Table 3 - Distribution of the reasons for discarding blood components in the coordinating blood center of the State of Paraná from 2010 to 2015 by unavoidable causes ( $n=43,843$ ). Curitiba, PR, Brazil, 2017

\begin{tabular}{|c|c|c|c|c|c|c|c|}
\hline \multirow{2}{*}{$\begin{array}{l}\text { Discards for } \\
\text { unavoidable causes }\end{array}$} & $\mathbf{C H}$ & $\mathbf{C P}$ & CRIO & PC & PFC & ST & Total \\
\hline & n (\%) & n (\%) & n (\%) & n (\%) & n (\%) & n (\%) & n (\%) \\
\hline \multirow{2}{*}{ Self-exclusion } & 2,003 & 834 & 141 & 67 & 1,403 & 51 & 4,499 \\
\hline & $(42.9)$ & $(15.4)$ & $(10.4)$ & $(0.8)$ & (6.2) & $(3.8)$ & $(10.3)$ \\
\hline \multirow{2}{*}{$\begin{array}{l}\text { Perforated bag and/ } \\
\text { or self-transfusion } \\
\text { bag expiration }\end{array}$} & 233 & 102 & 274 & 89 & 1,105 & 99 & 1,902 \\
\hline & (5.0) & (1.9) & $(20.2)$ & (1.1) & (4.9) & $(7.3)$ & $(4.3)$ \\
\hline \multirow{2}{*}{$\begin{array}{l}\text { Blocked by Social Service, } \\
\text { Lab or Collection }\end{array}$} & 305 & 106 & 55 & 16 & 267 & 58 & 807 \\
\hline & $(6.5)$ & $(2.0)$ & $(4.1)$ & $(0.2)$ & $(1.2)$ & $(4.3)$ & (1.8) \\
\hline \multirow{2}{*}{ Abnormal coloring } & 1 & 666 & 144 & 465 & 9,210 & 0 & 10,486 \\
\hline & $(0.0)$ & $(12.3)$ & $(10.6)$ & (5.6) & $(40.6)$ & $(0.0)$ & $(23.9)$ \\
\hline \multirow{2}{*}{$\begin{array}{l}\text { Whole blood } \\
\text { volume }<300 \mathrm{ml} \\
\text { and/or hematocrit } \\
\text { above parameter }\end{array}$} & 14 & 1 & 2 & 7 & 186 & 1,052 & 1,262 \\
\hline & $(0.3)$ & $(0.0)$ & $(0.1)$ & $(0.1)$ & (0.8) & $(77.5)$ & (2.9) \\
\hline \multirow{2}{*}{ Other reasons ${ }^{1}$} & 234 & 255 & 142 & 7,552 & 2,545 & 76 & 10,804 \\
\hline & (5.0) & $(4.7)$ & $(10.5)$ & $(90.3)$ & $(11.2)$ & (5.6) & (24.6) \\
\hline \multirow{2}{*}{$\begin{array}{l}\text { Positive irregular } \\
\text { antibody screening }\end{array}$} & 18 & 239 & 81 & 38 & 565 & 2 & 943 \\
\hline & $(0.4)$ & (4.4) & (6.0) & $(0.5)$ & $(2.5)$ & $(0.1)$ & $(2.2)$ \\
\hline \multirow{2}{*}{$\begin{array}{l}\text { Whole blood plasma } \\
\text { volume }<404 \mathrm{ml}\end{array}$} & 5 & 12 & 1 & 118 & 4,261 & 17 & 4,414 \\
\hline & $(0.1)$ & $(0.2)$ & $(0.1)$ & (1.4) & (18.8) & $(1.3)$ & $(10.1)$ \\
\hline \multirow{2}{*}{ Use for quality control } & 1,857 & 3,202 & 518 & 7 & 3,140 & 2 & 8,726 \\
\hline & $(39.8)$ & $(59.1)$ & $(38.1)$ & $(0.1)$ & (13.8) & $(0.1)$ & $(19.9)$ \\
\hline \multirow{2}{*}{ Total } & 4,670 & 5,417 & 1,358 & 8,359 & 22,682 & 1,357 & 43,843 \\
\hline & $(100.0)$ & $(100.0)$ & $(100.0)$ & $(100.0)$ & $(100.0)$ & $(100.0)$ & $(100.0)$ \\
\hline
\end{tabular}

Source: Hemovida/Datasus, 2017

Caption: CH: Red blood cell concentrate; (P: Platelet concentrate; CRIO: Cryoprecipitate; PC: Common plasma; PFC: Fresh frozen plasma; ST: Whole blood.

10ther reasons: The disposal situations not listed in Hemovida fall into place, such as surplus plasma stock; female plasma; previous self-exclusion less than a year ago; positive irregular antibody screening in previous donation. 
From the total number of potentially preventable disposals and based on the reimbursement values of each product, it was possible to estimate the financial amount not received, in reais and dollars, described in Table 4.

Table 4 - Financial cost of potentially avoidable disposal of blood components in the coordinating blood center from 2010 to 2015. Curitiba, PR, Brazil, 2017

\begin{tabular}{lcccc} 
& & \multicolumn{2}{c}{ Cost } \\
\cline { 3 - 5 } Blood components & Operational cost & $\mathbf{( n )}$ & Real (R\$) & Dollar (US\$) \\
\hline Red blood cell concentrate & 150.00 & 6,975 & $1,046,250.00$ & $278,257.98$ \\
Platelet concentrate & 135.00 & 16,282 & $2,198,070.00$ & $584,593.08$ \\
Cryoprecipitate & 100.00 & 1,687 & $168,700.00$ & $44,867.02$ \\
Fresh frozen plasma & 125.00 & 31,245 & $3,905,625.00$ & $1,038,730.05$ \\
Whole blood & 285.00 & 492 & $140,220.00$ & $37,292.55$ \\
Total & - & $\mathbf{5 6 , 6 8 1}$ & $\mathbf{7 , 4 5 9 , 8 6 5 . 0 0}$ & $\mathbf{1 , 9 8 4 , 0 0 6 . 6 5}$ \\
\hline
\end{tabular}

Source: Hemovida/Datasus, 2017

'Considering the value of the commercial US dollar against the real on January 27, 2019 (R\$3.76), according to the website https://www.dolarhoje.net.br.

\section{DISCUSSION}

In the production of whole blood and blood components in the coordinating blood center of the State of Paraná, the highest frequency of packed red blood cells $(39 \% ; n=177,543)$ and fresh frozen plasma (31.9\%; $n=145,352)$ stands out. These data are similar to the results of blood production in Brazil in 2014, with 8,324,711 units, including public and private services, of which $33.6 \%$ referred to red cell concentrate production $(n=2,799,759)$ followed by fresh frozen plasma with $28.9 \%(n=2,408,135)^{(12)}$. Red blood cell concentrate is known to be used in clinical practice to treat or prevent imminent and inadequate release of oxygen to tissues, such as acute hemorrhage and normovolemic anemia; and is usually requested in emergency situations, justifying more frequent use and the need for greater production by Brazilian blood centers ${ }^{(4)}$.

Federal government data show that among the blood component units produced in Brazil in 2014, more than 2.5 million were discarded, representing $31.8 \%$ of production ${ }^{(12)}$, higher than the findings of the present study regarding general disposal (22.3\%) and ranging from 6.6\% (platelet concentrate) to $80.2 \%$ (common plasma). According to the report on data from Brazilian blood production, the most commonly discarded blood component, in relation to production, was common plasma, representing 67.9\% and $81.6 \%$ of cases for 2014 and 2015, respectively ${ }^{(12)}$, consistent with the disposal identified in the present research.
When absolute numbers are observed, fresh frozen plasma is discarded, with 53,927 units (53\%) similar to national data, when more than one million bags were discard$\mathrm{ed}^{(12)}$. A study conducted at a blood bank in Iran showed that plasma bag discharges over the two-year period (2010 to 2012 ) were $93.9 \%$ of the total bags produced $(n=37,129)$. The study pointed out that puncturing of pouches due to technical failures during processing was the main reason for the disposal of fresh frozen plasma ${ }^{(13)}$.

The high index of this blood component may also be related to the lower frequency in the indication of plasma for transfusion, when compared to the packed red blood cells. To be accepted for the industrial production of blood products, the excess volume of fresh frozen plasma, common plasma and cryoprecipitate free plasma must be equal to or greater than $150 \mathrm{ml}$, presence of the collection tube attached to the pouch, integrity of the pouch/collecting tube, absence of red blood cells in the bag/collecting tube, non-lipemic, erythromic or green appearance, uniformity and horizontal freezing. That is, plasma pouches with inadequate quality parameters, in addition to not being suitable for transfusion, often cannot be used for the industrial production of blood products and, therefore, are discarded ${ }^{(14)}$.

Regarding the various reasons for disposal, the analysis allowed to estimate the avoidability potential. Lipemia was the most frequent discard reason, with limited avoidability potential. This condition results in a milky appearance of plasma and is a cause for non-compliance in the production process ${ }^{(15)}$. However, although visual inspection of 
plasma bags is, in practice, an indicator for disposal, methods for assessing the effectiveness of visual testing are not known, requiring the need for the periodic training of professionals to meet the technical specifications described in Brazilian legislation ${ }^{(5,16)}$. It is noteworthy that, in addition to the technical preparation of the professional, it is recommended that the donor eats adequately prior to donation in order to reduce cases of dyslipidemia and subsequent disposal of processed units ${ }^{(17)}$.

Red blood cell contamination was the second most frequent cause of discard (17.5\%; $n=10,147)$. A study in an Indian blood bank found that red blood cell contamination in platelet concentrate and fresh frozen plasma represented less than $0.1 \%$ of total discards ${ }^{(17)}$, unlike the findings in the present research. Contamination is related to greater adhesion of red blood cells to the inner walls of the blood bag due to the plastic material used to make them; to avoid the formation of lumps and red blood cell contamination, active homogenization of the post-collection bag is recommended, an essential maneuver in which employees should be trained ${ }^{(13,17)}$

Reagent serology, the third potentially preventable cause of disposal (16.7\%; n=9,672), demonstrates donors' lack of knowledge about their current health condition. In 2015, in the state of Paraná, the most frequent reagent serologies were Anti-HBC (Hepatitis B marker), with 1.5\%, followed by Syphilis $(0.8 \%)^{(12)}$. That same year, positive RBC concentrate serology in Latin American (38\%) and Caribbean (55\%) countries was the reason that exceeded discard of bags due to expiration date, a factor prevalent among platelet concentrate units ${ }^{(7)}$. Despite these findings, it is necessary to stimulate the donor's prior testing of infectious diseases, as well as to convey information in the main media about conscious donation. Strict adherence to criteria for donor selection, counseling and the use of software to identify positive donors for reactive serology are identified among the strategies to minimize blood disposal ${ }^{(17)}$.

Although considered a potentially avoidable reason for disposal, out-of-parameter volume implicitly brings a cause of difficult prevention, as it results from blood processing. In this research this reason corresponded to the disposal of 4,970 units (8.6\%), and could be minimized by preventive calibration of the equipment as well as by measures of hydration, feeding and rest of the donor in the pre-procedure period, reducing incomplete donations caused by vasovagal reaction ${ }^{(17)}$. However, it is noteworthy that even the collection of a volume within the parameters can generate insufficient volume of the byproducts, with consequent discard.
Expiration, with or without serology performed, represented $7 \%(n=4,086)$ of the discards with potential for reduction. In 2015, in Latin America, red blood cell and platelet concentrate disposal was also frequently associated with expiration of units ( $37 \%$ and $58 \%$, respectively) $)^{(7)}$. This reason for disposal is considered preventable and can be reduced by distributing them among the services that make up the state hemo network.

The amount of blood components to be collected and produced must maintain a balance, based on reliable forecasting, to meet requests. However, production above demand contributes to disposal. It is noted that shelf life is dependent on blood product and storage conditions and ranges from five days (platelet concentrate) to two years (plasma products) ${ }^{(4)}$. A research conducted in a blood bank in India found that among 4,026 discarded blood components, the highest prevalence was platelet concentrate (47.7\%), and the main reason (96.6\%) was expiration due to non-use ${ }^{(18)}$. Thus, the need is reiterated to identify whether or not the discard due to expiration is a a consequence of excess production or not. And, in this case, also the need to balance inventory with demand.

In the present research, it was found that the reasons for disposal related to donor registration and identification, transportation, storage and thawing, accounted for 3.5\% of the cases $(n=2,040)$, with the possibility of reducing its occurrence. Examples include the elaboration and periodic updating of Standard Operating Procedures, supervision and validation of processes, as well as educational activities for those involved in each stage of the blood cycle. These interventions were positive for reducing blood waste in a transfusion center located in West Asia. Cost savings were estimated at US\$ 1,500,000 ${ }^{(13)}$.

According to the Brazilian Ministry of Health, red blood cell concentrates without an additive solution should have a hematocrit between $65 \%$ and $80 \%$ and, in cases of bags with an additive solution, this may vary from 50 to $70 \%{ }^{(5)}$. In this research, it was observed that disposals due to hematocrit below the recommended parameters represented a lower frequency among potentially preventable causes, which highlights the importance of semi-automated procedures to avoid the waste of processed red cell concentrate bags.

A study conducted in India regarding the causes of 615 blood bags discarded showed that abnormal plasma staining and hemolysis accounted for $1.3 \%(n=8)^{(18)}$, lower than what was found in this research $(23.9 \% ; n=10,486)$, indicating the possibility of improving processing. The use of blood components for quality control accounted for $19.9 \%$ $(n=8,726)$ of discarded units. This destination is regulated 
by the Brazilian Ministry of Health, and is an important step in the safe use of blood ${ }^{(5)}$.

Although blood processing is performed by professionals only, it is possible that some technical errors lead to nonconformities and consequent product disposal. As an example, discard by swirling $<2+$, visual inspection criterion for quality control of platelet concentrate, is cited. Considering the subjective aspect of this evaluation and the frequency of discards for this reason, the need for technical training and continuing education of the team is inferred in order to minimize errors.

Reported as "other reasons", 10,804 units (24.6\%) of blood were discarded, resulting from the fact that the Hemovida System presents this field, without being linked to the details of the cause. Thus, it was not possible to know what these reasons were, which is considered as a limitation of the research because it often surpasses several of the nominally informed causes.

As for the financial costs of potentially avoidable whole blood and blood component disposals, it has been estimated at approximately $\mathrm{R} \$ 760$ million, equivalent to approximately US\$ 2 million, if we consider that only one unit of packed red blood cells costs, with underestimated values, $R \$ 150$ or US\$ 39.9. An Indian study found that in a large blood bank, the disposal of 6,777 units of whole blood and red blood cells (2012-2016) by expiration alone accounted for approximately US\$100,000, considering a unit value of US\$1 $15^{(19)}$.

The cost involved in managing the use of blood components results in the generation of health waste, a major environmental and public health problem, adding even more cost to the production of blood components, as some states hire companies to dispose of its biological waste. A Brazilian study conducted with data from inspections in hemotherapy services in 2013 indicated important compliance to be observed in the blood cycle. Among these, it highlighted protocols for the control of indications and disposal of blood components, as well as compatible areas for waste disposal ${ }^{(20)}$.

The high rate of disposal reiterates the need to control the main reasons for even reducing the waste of financial resources also due to waste treatment. These add cost to their disposal, in addition to the expenses with materials and procedures used in the collection, processing and other stages of the blood cycle. The starting point was the assumption that in view of the disposal of blood components for potentially preventable causes, the coordinating blood center of the State of Paraná stopped supplying these products and, therefore, was not reimbursed; although there were financial expenses. Thus, it is necessary to intensify measures to reduce the various reasons related to the disposal of blood bags. These should be in line with the strategies outlined in the action plan (2014/2019) for universal access to safe blood in Latin American and Caribbean countries ${ }^{(7)}$.

\section{CONCLUSION}

It was concluded that the disposal of blood and blood components occurred mainly for potentially preventable causes, such as lipemia, red blood cell contamination and reagent serology, generating an approximate cost of US\$ 2 million for the public service. The results show the potential for the avoidability of discards and of financial waste. The results are expected to be an important input to improve actions to reduce disposal through planned and coordinated actions such as process and logistics review, in-service training and continuing education of technical staff. The establishment of a quality management committee, focusing on the technical and operational causes associated with disposal, may contribute to its avoidability; as well as the wide dissemination to the population of criteria for blood donation and impediments related to lipemia and positive serology. Recognizing blood as a product of extreme importance in clinical practice, the reduction of avoidable discards will contribute to the precise management of the patient who needs it, by promoting and managing the stocks in blood centers, hemonuclei and hospital units.

This study may instigate teaching units in technical and university education, and consequent research studies aimed at recognizing the problem, and possible actions for continuous improvement in the various stages of the blood cycle, with direct impact on costs. Although the reference table in force for the estimated costs is from 2006, with consequent mismatch in the described base values, the conversion of the values to US dollars allowed the present financial values to be more current.

Noteworthy among the study limits are failures in records, inconsistencies and underreporting in the database. The lack of national and international studies addressing the financial costs of blood and blood component discards demonstrates a knowledge gap that has hindered greater theoretical support and comparison between services and countries. It is suggested that research focusing on this theme be conducted to highlight the need for actions to better use the donated product and the public resources.

\section{REFERENCES}

1. World Health Organization [Internet]. Geneva:WHO; c2017- [cited 2018 Nov 05]. Blood safety and availability; [about 1 screen]. Available from: https://www.who. int/en/news-room/fact-sheets/detail/blood-safety-and-availability 
2. Agência Nacional de Vigilância Sanitária (BR). Relatório do universo de estabelecimentos cadastrados, segundo dados da Vigilância Sanitária. Brasília: Ministério da Saúde; 2015 [cited 2018 Dec 10]. [Boletim de serviços de hemoterapia no Brasil, 01]. Available from: http://portal. anvisa.gov.br/documents/219201/219401/boletim_hemoterapia_ brasil_1\%2B\%25282\%2529.pdf/7fb452a0-3607-4374-8f80-55760f13248a

3. Ministério da Saúde (BR). Secretaria de Atenção à Saúde. Departamento de Atenção Especializada e Temática. Caderno de informação: sangue e hemoderivados: dados de 2014. 9. ed. Brasília: Ministério da Saúde; 2015 [cited 2018 Dec 10]. Available from: http://bvsms.saude.gov.br/bvs/publicacoes/ caderno_informacao_sangue_hemoderivados_dados_201_9ed.pdf

4. Ministério da Saúde (BR). Secretaria de Atenção à Saúde. Departamento de Atenção Especializada e Temática. Manual de orientações para promoção da doação voluntária de sangue. Brasília: Ministério da Saúde; 2015 [cited 2018 Dec 10]. Availalble from: http://bvsms.saude.gov.br/bvs/publicacoes/manual_ orientacoes_promoca__doaca_voluntaria_sangue.pdf

5. Ministério da Saúde (BR). Portaria no 158, de 04 de fevereiro de 2016. Redefine o regulamento técnico de procedimentos hemoterápicos. Diário Oficial da União [da] República Federativa do Brasil. 2016 fev 5;153(25 Seção 1):37-57.

6. Ministério da Saúde (BR). Portaria nº 1.469, de 10 de julho de 2006. Dispõe sobre o ressarcimento de custos operacionais de sangue e hemocomponentes ao Sistema Único de Saúde (SUS), quando houver fornecimento aos nãousuários do SUS e instituições privadas de saúde. Diário Oficial da União [da] República Federativa do Brasil. 2006 jul 11;143(131 Seção 1):41-2.

7. Organización Panamericana de la Salud (US). Suministro de sangre para transfusiones en los países de Latinoamérica y del Caribe 2014 y 2015. Washington, DC: OPS; 2017 [cited 2018 Aug 12]. Available from: http://iris. paho.org/xmlui/bitstream/handle/123456789/34082/9789275319581-spa. pdf?sequence $=1 \&$ isAllowed $=y$

8. Governo do Paraná (BR). Secretaria de Estado da Saúde do Paraná. Plano Estadual de Saúde Paraná 2016-2019. Curitiba; 2016 [cited 2018 May 24]. Available from: http://www.saude.pr.gov.br/arquivos/File/PlanoEstadualSaude2016MioloAlt. pdf

9. Centro de Hematologia e Hemoterapia do Paraná [Internet]. Curitiba: Hemepar; c2019- [cited 2019 Jul 04]. Quem somos?; [about 8 telas]. Available from: http://www.hemepar.pr.gov.br/\#section-section2

10. Ministério da Saúde (BR). Departamento de Informática do Sistema Único de Saúde. Hemovida - Sistema de Gerenciamento em Serviços de Hemoterapia. Brasília: Ministério da Saúde; 2017 [cited 2018 May 24]. Available from: http:// datasus.saude.gov.br/sistemas-e-aplicativos/hospitalares/hemovida
11. Covo MZ. Matriz de recomendações para melhoria de desempenho do ciclo do sangue no Hemocentro Coordenador do Estado do Paraná [dissertação]. Curitiba (PR): Universidade Federal do Paraná; 2018 [cited 2019 Jul 04]. Available from: https://acervodigital.ufpr.br/handle/1884/59402

12. Agência Nacional de Vigilância Sanitária (BR). 40 Boletim de Produção Hemoterápica: Hemoprod 2014 e 2015. Brasília: Ministério da Saúde; 2017 [cited 2018 Dec 10]. Available from: http://portal.anvisa.gov.br/documents/4048533 $15234223 / 4 \%$ C2\%BA+Boletim+de+Produ\%C3\%A7\%C3\%A30+Hemoter \%C3\%A1pica+2017/a1cca083-53f7-4fba-943b-678374402051?version=1.2

13. Javadzadeh Shahshahani $H$, Taghvai N. Blood wastage management in a regional blood transfusion centre. Transfus Med. 2017;27(Suppl 5):348-53. doi: https://doi.org/10.1111/tme.12433

14. Ministério da Saúde (BR). Empresa Brasileira de Hemoderivados e Biotecnologia. Caderno de Especificações Técnicas do Plasma para Fracionamento Industrial. Brasília: Hemobrás; 2014.

15. Sánchez Frenes P, Sánchez Bouza MJ, Mena Rodríguez E, Seijo Pérez O, Bastida Goitizolo 0, Castillo Monzón E. Is the pre-donation lipemia test useful for blood donor selection? Rev Cubana Hematol Inmunol Hemoter. 2014 [cited 2018 Dec 12];30(3):265-72. Available from: http://scielo.sld.cu/scielo.php?script=sci_ arttext\&pid=S0864-02892014000300009\&lng=es

16. Barbosa FP, Barbosa TC, Quaresma FRP, Silva Maciel E. Prevalência de bolsas lipêmicas na produção de plasmas em um Hemocentro da região Norte do Brasil. Rev Amazônia: Sci Health. 2015 [cited 2018 Nov 12];3(1):15-20. Available from: http://ojs.unirg.edu.br/index.php/2/article/view/826

17. Kanani AN, Vachhani JH, Dholakiya SK, Upadhyay SB. Analysis on discard of blood and its products with suggested possible strategies to reduce its occurrence in a blood bank of tertiary care hospital in Western India. Glob J Transfus Med. 2017;2(2):130-6. doi: https://doi.org/10.4103/GJTM.GJTM_34_17

18. Chavan SK. Determination of rate and analysis of reasons for discarding blood and blood components in a blood bank of tertiary care hospital: a retrospective study. Int J Res Med Sci. 2017;5(3):1111-5. doi: https://doi.org/10.18203/2320$6012 . j \mathrm{jrms} 20170671$

19. Jariwala K, Mishra K, Patel G, Seliya R, Shukla R, Ghosh K. Reasons for discarding of whole blood/red cell units in a Regional Blood Transfusion Centre in Western India. Indian J Hematol Blood Transfus. 2018;34(3):501-5. doi: https://doi. org/10.1007/s12288-017-0903-Z

20. Silva Júnior JB, Rattner D, Martins RCA. Controle de riscos potenciais em serviços de hemoterapia no Brasil: uma abordagem para autoridades reguladoras. Rev Panam Salud Publica. 2016 [cited 2018 Dec 12];40(1):1-8. Available from: https://www.scielosp.org/article/rpsp/2016.v40n1/1-8/

\section{Corresponding author:}

Magali Zimmermann Covo

E-mail: magazmm@gmail.com
Received: 02.16.2019

Approved: 07.17.2019 